\title{
Sulfurimonas subgroup GD17 cells accumulate polyphosphate under fluctuating redox conditions in the Baltic Sea: possible implications for their ecology
}

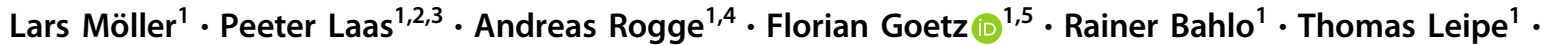 \\ Matthias Labrenz ${ }^{1}$
}

Received: 20 December 2017 / Revised: 4 May 2018 / Accepted: 11 May 2018 / Published online: 5 October 2018

(c) International Society for Microbial Ecology 2018

\begin{abstract}
The central Baltic Sea is characterized by a pelagic redox zone exhibiting high dark $\mathrm{CO}_{2}$ fixation rates below the chemocline. These rates are mainly driven by chemolithoautotrophic and denitrifying Sulfurimonas GD17 subgroup cells which are motile and fast-reacting $r$-strategists. Baltic Sea redox zones are unstable and a measurable overlap of nitrate and reduced sulfur, essential for chemosynthesis, is often only available on small scales and short times due to local mixing events. This raises the question of how GD17 cells gain access to electron donors or acceptors over longer term periods and under substrate deficiency. One possible answer is that GD17 cells store high-energy-containing polyphosphate during favorable nutrient conditions to survive periods of nutrient starvation. We used scanning electron microscopy with energy-dispersive X-ray spectroscopy to investigate potential substrate enrichments in single GD17 cells collected from Baltic Sea redox zones. More specific substrate enrichment features were identified in experiments using Sulfurimonas gotlandica GD1 ${ }^{\mathrm{T}}$, a GD17 representative. Sulfurimonas cells accumulated polyphosphate both in situ and in vitro. Combined genome and culture-dependent analyses suggest that polyphosphate serves as an energy reservoir to maintain cellular integrity at unfavorable substrate conditions. This redox-independent energy supply would be a precondition for sustaining the $r$ strategy lifestyle of GD17 and may represent a newly identified survival strategy for chemolithoautotrophic prokaryotes occupying eutrophic redox zones.
\end{abstract}

\section{Introduction}

Marine systems such as the Baltic Sea, Black Sea, and the Cariaco Basin are characterized by a practically permanent

Electronic supplementary material The online version of this article (https://doi.org/10.1038/s41396-018-0267-x) contains supplementary material, which is available to authorized users.

Matthias Labrenz

matthias.labrenz@io-warnemuende.de

1 Department of Biological Oceanography, Leibniz Institute for Baltic Sea Research Warnemünde (IOW), Rostock, Germany

2 Department of Marine Systems, Tallinn University of Technology, Tallinn, Estonia

3 Fort Lauderdale Research and Education Center, University of Florida, Davie, FL, USA

4 Alfred Wegener Institute (AWI), Bremerhaven, Germany

5 Woods Hole Oceanographic Institution, Falmouth, MA, USA oxygen depletion zone [1-5]. In these systems, reduced sulfur compounds, especially hydrogen sulfide, are produced by the anaerobic microbial decomposition of organic matter $[6,7]$.

The typical transition zone between oxidized and reduced water bodies is referred to as the redox zone and it contains a high microbial abundance and activity. The latter includes the catalysis of important biogeochemical transformation processes [8]. In the Baltic Sea, one of the organismal groups predominating within its redox zones belongs to the Epsilonproteobacteria, represented by the Sulfurimonas GD17 subgroup. GD17 cell counts are highest below the chemocline, defined as the depth marked by the first appearance of sulfide [9-11]. Bacteria of the Sulfurimonas GD17 subgroup are anaerobic sulfur oxidizers and denitrifiers, adapted to waters with sulfide concentrations ranging from $<10$ to $20 \mu \mathrm{mol} \mathrm{L}^{-1}[12,13]$.

The successful isolation of a representative of the GD17 subgroup, Sulfurimonas gotlandica strain GD1 ${ }^{\mathrm{T}}$, has provided a model organism for studies of biogeochemical 


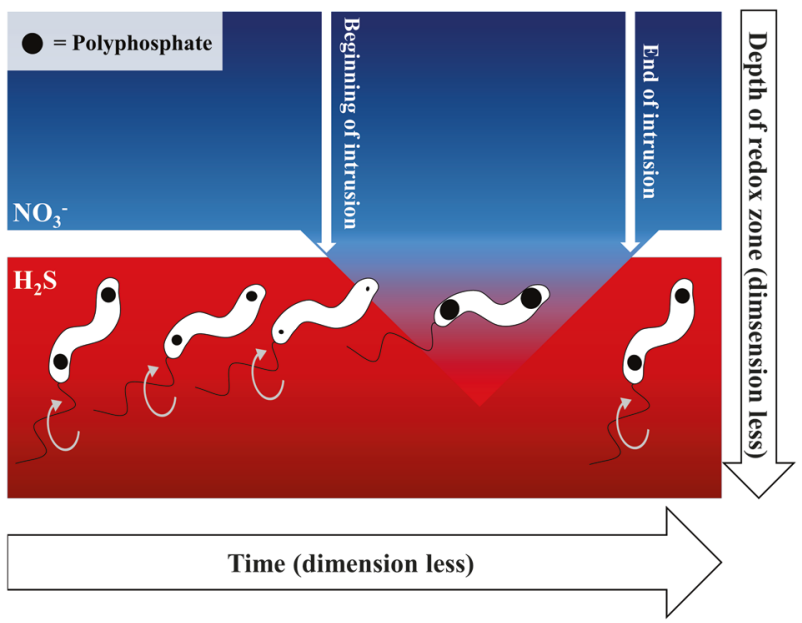

Fig. 1 Transition zones between oxidized and reduced water masses provide favorable habitats for chemolithoautophic microorganisms. Mixing events, such as micro-scale intrusions, create overlapping zones where suitable electron acceptors (including $\mathrm{NO}_{3}{ }^{-}$) and electron donors (including $\mathrm{H}_{2} \mathrm{~S}$ ) co-localize. We hypothesize that under these conditions $S$. gotlandica $\mathrm{GD} 1^{\mathrm{T}}$ cells accumulate polyphosphate, using it as an energy source to sustain cellular integrity, which is a precondition to enable motility to new favorable zones

cycling in the Baltic Sea redox zone [12-14]. In the central Baltic Sea, even though the redox zone itself is relatively stable, local mixing events or lateral intrusions can occur [15], introducing nitrate-containing water masses in sulfidic zones and vice versa. The result is a redox zone of fluctuating redox potentials on smaller scales. In situ substrate incorporation analyses using nano secondary ion mass spectrometry (NanoSIMS) on a single-cell level showed that $S$. gotlandica subgroup GD17 cells are fast-reacting $r$ strategists that depend on these intrusions for growth [13]. However, in this fluctuating system, where the loss of essential donors or acceptors is a constant threat, it is unclear how $S$. gotlandica subgroup GD17 cells gain access to the energy sources they need for chemosynthesis. Accumulation and storage are possibilities and both have been well documented in other chemolithoautotrophic bacteria, such as Beggiatoa, Thioploca, and Thiomargarita, which store sulfur, nitrate, or both [16-19]. Although earlier studies suggested a similar ability for Sulfurimonas present in the Baltic Sea [11], it has yet to be demonstrated.

Thus, the aim of our study was to examine the potential substrate storage capabilities of Sulfurimonas subgroup GD17. However, with a mean volume of $0.6 \mu \mathrm{m}^{3}$ [13], Sulfurimonas cells are much smaller than the abovementioned chemolithoautotrophic bacteria, limiting intracellular storage capacities. Thus, instead of sulfur or nitrate as only precursors for energy generation, we expected an enrichment of polyphosphate to be a more comprehensive and beneficial cellular storage system within unstable marine redox zones. Polyphosphate consists of linear polymers based on tens to hundreds of phosphate residues which are linked by highly energetic phosphoanhydride bonds. As a final product it represents both a redoxindependent and rich source of energy. Cellular polyphosphate enrichment is a well-known feature of numerous prokaryotic taxa and contributes to a wide variety of cellular functions. For instance, in Beggiatoa, polyphosphate may provide energy as part of a cellular "safety system" that is active in the absence of a suitable electron acceptor [20]. Polyphosphate can also be accumulated in response to certain conditions: for purposes of phosphorus storage [2123], as an adenosine triphosphate (ATP) substitute [24, 25], as a factor in stress responses [20,26-28], as an adaptation to the stationary phase of the cell cycle [29], as a pH buffer system [30], in the control of gene activity [31], for energy storage [32] and in the upkeep of motility [33, 34]. Recently, it has been shown for the oxic-anoxic interface in the water column of the ferruginous Lake Pavin that magnetotactic bacteria of the family Magnetococcaceae accumulate polyphosphates and could significantly contribute to the $\mathrm{P}$ cycle in this environment [35].

Our hypothesis was that, as shown in Fig. 1, mixing events in pelagic Baltic Sea redox zones provide areas where suitable electron acceptors and electron donors colocalize for the chemosynthesis of Sulfurimonas subgroup GD17. In these conditions $S$. gotlandica $\mathrm{GD}^{\mathrm{T}}$ cells accumulate polyphosphate. Preserving cellular integrity, potentially linked to motility, for a longer time period, this redoxindependent energy supply would be a prerequisite for the maintenance of the $r$-strategy lifestyle of Sulfurimonas subgroup GD17/GD1 ${ }^{\mathrm{T}}$.

The hypothesis was tested by polyphasic in situ and in vitro approaches. For our in situ approach, we took advantage of the fact that dark $\mathrm{CO}_{2}$ fixation measurements have already demonstrated the high cellular density of most chemolithoautotrophic prokaryotes in sulfidic zones of the Baltic Sea [36]. As the major chemolithoautotrophic cluster in the redox zone, Sulfurimonas subgroup GD17 was expected to comprise these high-density cells. Accordingly, we isolated the chemolithoautotrophic cluster by flow cytometry, identified the bacterial composition, and determined the features of cellular substrate enrichment. In vitro experiments using $S$. gotlandica strain $\mathrm{GD}^{\mathrm{T}}$ were performed to identify the ecological features associated with the potential substrate storage capability of the cells.

\section{Materials and methods}

A detailed description of the material and methods used in this study is available online in the Supplementary Methods. 


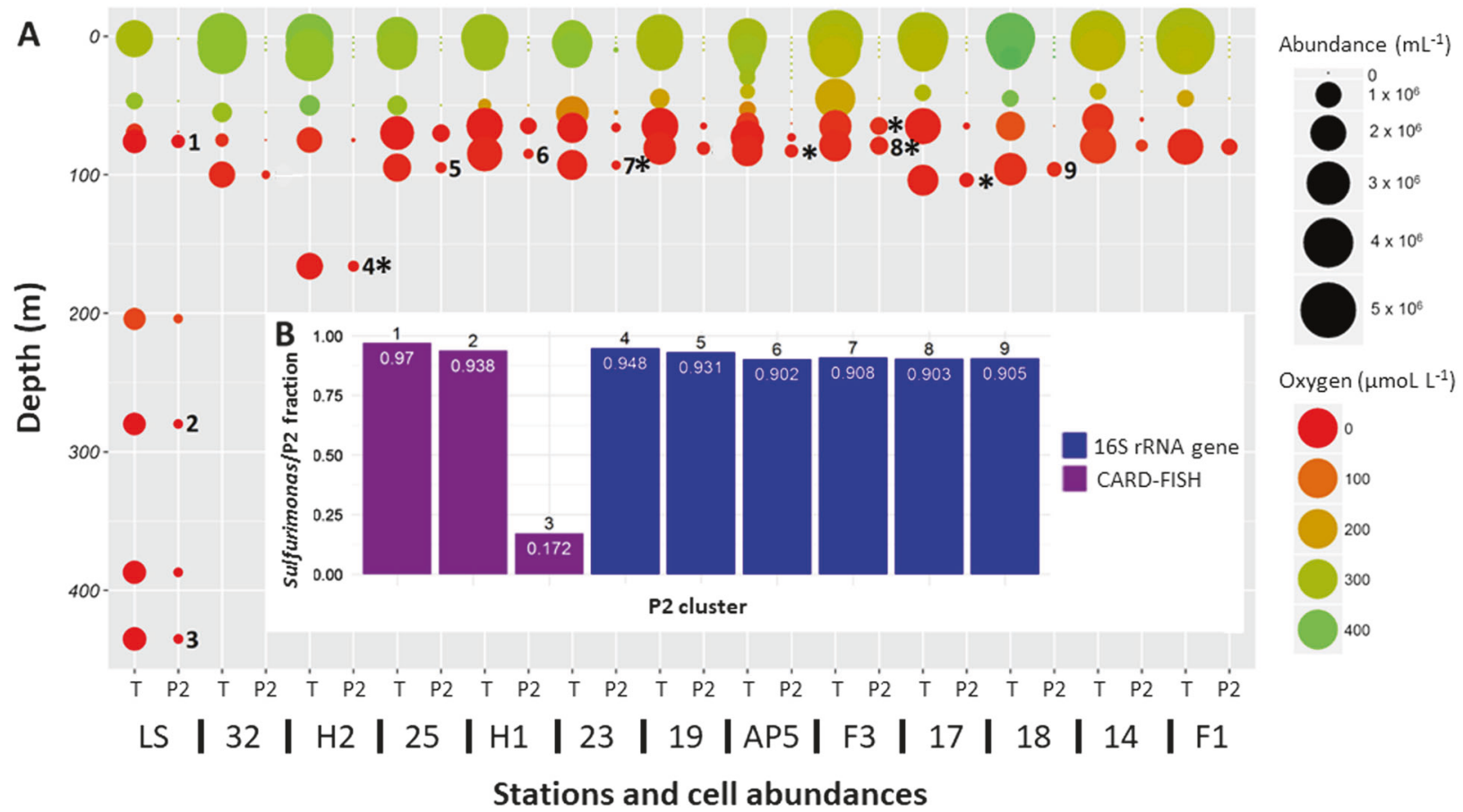

Fig. 2 In situ analyses. a Specific high nucleic acid-containing, high side scatter cluster P2 cell abundances and the total cell abundances (T) outside cluster P2 as determined at 13 different Baltic Sea stations. Nine P2 clusters (labeled 1-9) were selected for cell sorting, followed by CARD-FISH analyses or 16S rRNA gene identification. b Relative abundance of $S$. gotlandica strain GD1 1 GD17 cells determined by

\section{Sulfurimonas subgroup GD17 in situ sampling and processing}

\section{Sampling}

Water samples from the Gulf of Finland were collected onboard the R/V Salme in July 2014 and from the Landsort Deep on-board the R/V Poseidon in August 2015 (Supplementary Fig. S1; Supplementary Table S1). Flow cytometry samples for cellular-based analyses were fixed with paraformaldehyde and glutaraldehyde $(\mathrm{P}+\mathrm{G}$, final concentrations 1 and $0.05 \%$, respectively; $\mathrm{pH}=7.4$ ) and incubated at $4{ }^{\circ} \mathrm{C}$ for $60 \mathrm{~min}$. Subsamples for downstream molecular analyses were preserved in dimethyl sulfoxide (DMSO) at a final concentration of $15 \%$ and stored at $-80^{\circ}$ C.

\section{Cell isolation by flow cytometry}

The cells were sorted on a BD FACSAria III (Becton, Dickinson and Company; see Supplementary Methods). Events within high nucleic acid and high side scatter clusters (HNA-hs) were attributed to GD17 (P2 cluster in Figs. 2-4). Cells within and without the P2 cluster were sorted, collecting between 500,000 and 1,000,000 cells in 2
CARD-FISH (P2 clusters 1-3); 16S rRNA gene abundances of Sulfurimonas spp. (P2 clusters 4-9). *P2 cluster samples used for substrate enrichment analyses by SEM-EDX. Number of cells containing polyphosphate versus polyphosphate-free cells was: 1/294 (station H2), 3/143 (station 23), 1/217 (station AP5); 0/85 (77 m), 281/25 (79 m) (station F3), 0/103 (station 17)

$\mathrm{mL}$ Eppendorf tubes. The sorted samples were prepared and used for (a) scanning electron microscopy-energy-dispersive X-ray spectroscopy (SEM-EDX) analyses $(\mathrm{P}+\mathrm{G}$ fixed) to detect cellular substrate enrichments; (b) GD17 identification by $16 \mathrm{~S}$ rRNA gene analyses (DMSO-fixed); (c) GD17 quantification using the SUL90 gene probe and fluorescence in situ hybridization combined with catalyzed reporter deposition (CARD-FISH $(\mathrm{P}+\mathrm{G}$ fixed)) [9].

\section{Molecular identification and quantification}

DMSO-preserved P2 cluster samples were pelleted and used for direct PCR amplification. Amplicons of the obtained $16 \mathrm{~S}$ rRNA gene V2 hypervariable region were sequenced on the Illumina MiSeq platform (The Estonian Genome Center Core Facility) and phylogenetically analyzed as described earlier [37]. Sorted P2 samples from the Landsort Deep were used for CARD-FISH analyses.

\section{Nucleotide sequence accession numbers}

The 16S rRNA gene sequences determined in this study have been deposited in the National Center for Biotechnology Information (NCBI) Popset Database under accession numbers KT86004455220-KT860044. 


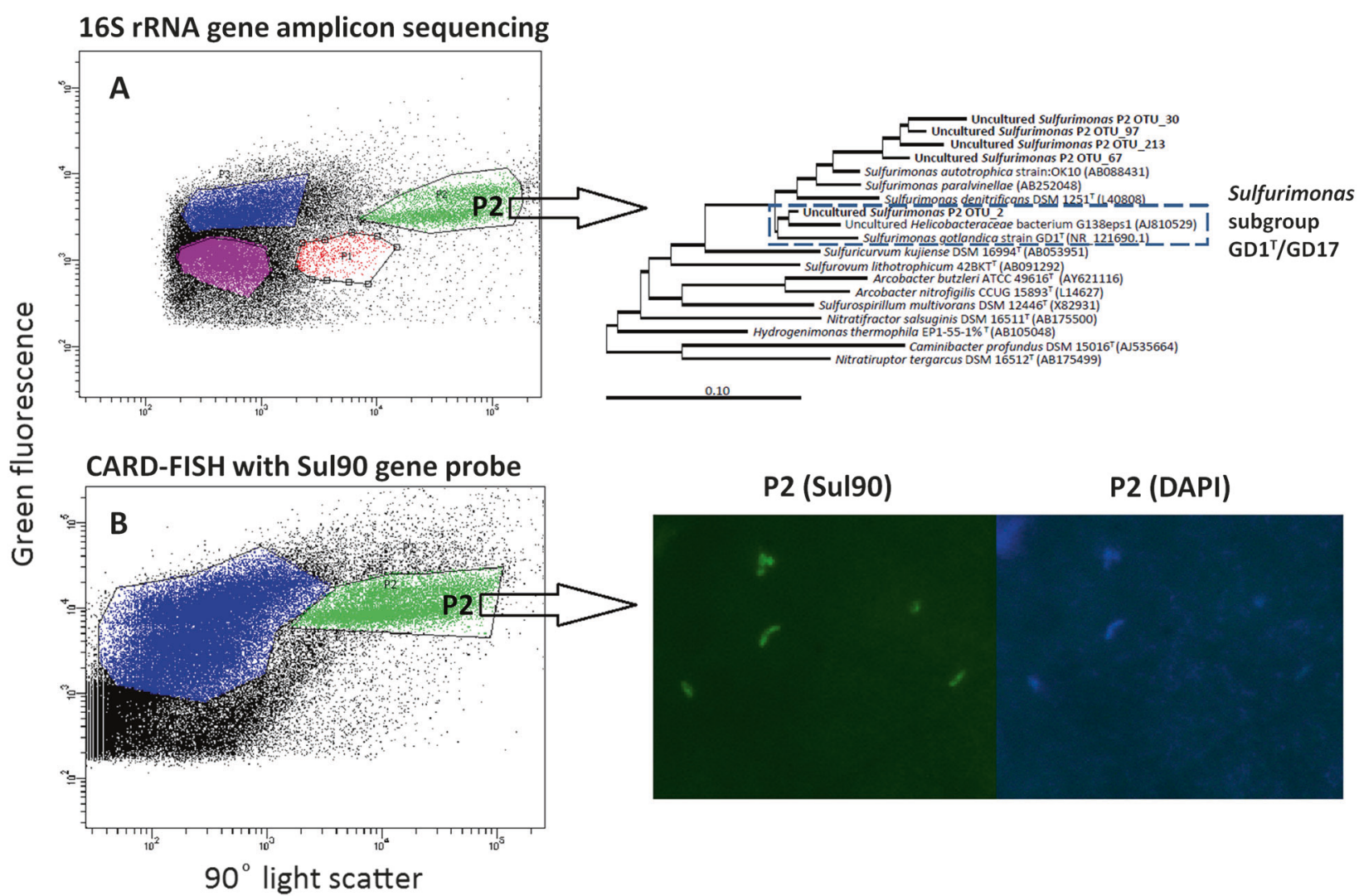

Fig. 3 Approach to identify and quantify Sulfurimonas spp. cells in the high nucleic acid, high side scatter cluster P2. BD FACSAria III was used to sort out the P2 cluster (green gate) from SYBRGreen-I-stained samples. a Sorted cells were identified by parallel sequencing of $16 \mathrm{~S}$ rRNA gene sequences amplified via direct PCR. OTU2, which clusters together with "uncultured Helicobacteraceae bacterium G138eps1"

\section{Polyphosphate identification}

Cellular element composition was analyzed by SEM (Zeiss Merlin $^{\circledR}$ Compact VP) combined with EDX (Oxford Instruments; AZtec 3.3. and Inca software) using XMaxN80 EDX detector. The cells were filtered onto 0.2 $\mu \mathrm{m}$ polycarbonate filters (Whatman Nucleopore), dried at room temperature, and chrome-coated (vacuum sputter) before their analysis for electrical conductivity. A total of 25,396 potential particles (between 1494 and 5993 per sample) were automatically spotted by the AZtec program and their elemental composition identified by several measurements on the features. The accelerating voltage was 10 $\mathrm{kV}$ with a working distance of 8.5 and a microscope magnification of 3000 . The EDX measurement was calculated by stoichiometry and normalized to $100 \%$. Deconvolution elements were carbon and chrome. Eventually, particles were controlled by eye to discriminate abiotic particles from bacterial cells. Only those cells with phosphorus contents between 20 and $60 \%$ were labeled as phosphorus enriched. To identify polyphosphate, point identification was used for (the first 16S rRNA gene sequence published representing Sulfurimonas subgroup GD17 [10]), and Sulfurimonas gotlandica $\mathrm{GD} 1^{\mathrm{T}}$ were used to determine relative $16 \mathrm{~S}$ rRNA gene abundance. b Quantification of sorted cells by CARD-FISH staining using the Sul90 probe which targets the Sulfurimonas GD1 ${ }^{\mathrm{T}} / \mathrm{GD} 17$ subgroup

elements nitrogen, phosphorus, sulfur, oxygen, magnesium, and calcium on 39 single cells. These selected cells were analyzed using the line scan mode with 200 points of measurement each.

\section{Sulfurimonas $\mathrm{GD}^{\top}{ }^{\top}$ in vitro analyses}

\section{Cultivation}

S. gotlandica strain $\mathrm{GD} 1^{\mathrm{T}}$ cells were cultivated in a modified artificial brackish water (ABW) medium under anoxic conditions [38], as described in Labrenz et al. [14]. $\mathrm{NaHCO}_{3}$ was provided as the carbon source at a final concentration of $2 \mathrm{mmol} \mathrm{L}^{-1}$. The medium was supplemented with $10 \mathrm{mmol} \mathrm{KNO}_{3} \mathrm{~L}^{-1}$ (variations in some experiments, see Supplementary Methods) as the electron acceptor. One of two different compounds (thiosulfate, elemental sulfur) was used as the electron donor and added in variable concentrations depending on the experimental setup. All supplements were prepared anoxically and sterilized before usage: $\mathrm{KNO}_{3}$ and thiosulfate was autoclaved 
and sulfur tyndallized. The cultures were incubated at $15{ }^{\circ} \mathrm{C}$ in the dark. Cultures with elemental sulfur as the electron donor were incubated on a tilting table at $60 \mathrm{rpm}$. The cells were counted and observed by nucleic acid staining using DAPI (4,6-diamidino-2-phenylindol) and epifluorescence microscopy as described by Grote et al. [12].

\section{Physiological and morphological S. gotlandica GD1 ${ }^{\top}$ features}

A polyphasic approach was used to identify the potential role of polyphosphate for $\mathrm{GD}^{\mathrm{T}}$. (a) The chemical composition of cellular element enrichments was identified in SEM-EDX analyses of 36 cells as described above. (b) Polyphosphate and protein production during the different GD1 ${ }^{\mathrm{T}}$ growth phases was quantified. Polyphosphate quantification was based on Martin and Van Mooy [39] with a slight modification in buffer composition according to Kulakova et al. [40]. For protein quantification Bio-Rad Quick StartTM Bradford Protein Assay was used. (c) The motility speed of cells grown in the presence of different electron donor and acceptor concentrations was measured. For this, GD1 ${ }^{\mathrm{T}}$ was cultivated as described above in ABW medium supplemented with 6 different electron thiosulfate/ nitrate concentrations, ranging from $10 \mu \mathrm{mol} \mathrm{L}^{-1}$ up to 10 $\mathrm{mmol} \mathrm{L}{ }^{-1}$. Cultures were incubated for 7 days and then transferred on self-prepared objective slides with an anoxic chamber on it. Cells were recorded using a microscope (Zeiss AXIO star plus) mounted with a camera (Nikon D300s) for up to $10 \mathrm{~s}$. Super@, a freeware tool, was used to extract data from all videos. Resulting bmp data were analyzed using the freeware program "Trace" (Heribert Cypionka, 2000-2010). Analogously to Fischer and Cypionka [41], individual cells were identified by the program and tracked over recorded times to measure the motility speed. Motility speeds of 436 cells were measured in total. (d) The influence of polyphosphate inclusions on GD $1^{\mathrm{T}}$ cell integrity was assayed in a 90-day incubation experiment, where only nitrate was supplemented as electron acceptor. The test design was based on Adler and Dahl [42] and the described gradient experiment to examine the influence of different polyphosphate concentration on cellular integrity. Defined numbers of nutrient-free ABW medium-washed high-polyphosphate-containing cells and low-polyphosphate-containing cells were placed on the bottom of glass tubes containing nutrient-free ABW soft agar with a nitrate-containing solid top agar. Tubes were incubated for 90 days in an anoxic atmosphere, at $15^{\circ} \mathrm{C}$ in the dark. After incubation, tubes were split in $2 \mathrm{~cm}$ sections and the semi-solid agar of each part was prepared for DAPI counting. (e) An incubation experiment was carried out for 23 days to test chemotactic movement in a thiosulfatenitrate gradient. Test tubes were prepared with semi-solid agar in the middle flanked by solid top agar containing nitrate and solid bottom agar containing thiosulfate. Inoculated tubes were incubated for 23 days. After the incubation, the tubes were opened and the semi-solid medium was divided into $8 \times 1 \mathrm{~mL}$ sections. Cell counts in these layers were determined using DAPI staining.

\section{Results}

\section{Identification and isolation of environmental Sulfurimonas subgroup GD17 cells}

\section{GD17 identification and quantification}

Earlier $\mathrm{NaH}_{14} \mathrm{CO}_{3}$ tracer incubation experiments using central Baltic Sea redox zone waters followed by flow cytometric cell sorting and $\mathrm{CO}_{2}$ fixation rate measurements identified already distinct flow cytometric high side scatter clusters with prokaryotes of high nucleic acid content being responsible for 65 to $100 \%$ of the total dark fixation [36]. As the major chemolithoautotrophic taxon in the redox zone [43], Sulfurimonas subgroup GD17 was expected to comprise these high-density cells [9-11, 36]. However, this hypothesis remained unproven and had to be confirmed first to enable a linkage between environmental Sulfurimonas identity and potential polyphosphate enrichment. Accordingly, we isolated the HNA-hs clusters, identified their bacterial composition and Sulfurimonas cell abundance. Water samples for flow cytometry analyses were collected from the Gulf of Finland and the Landsort Deep and revealed the presence of HNA-hs clusters in all hypoxic and sulfidic areas investigated (Figs. 2, 3; cluster P2). Parallel sequencing analyses of 16S rRNA gene amplicons based on six different samples demonstrated that Sulfurimonas spp. contributed $91.6 \%( \pm 1.9 \%)$ of the $16 \mathrm{~S}$ rRNA genes of the P2 clusters (Fig. 2b). The most abundant OTU2 (Fig. 3a) was a member of the Sulfurimonas GD1 ${ }^{\mathrm{T}} / \mathrm{GD} 17$ subgroup $(84.1 \%( \pm 1.5 \%)$ of all $16 \mathrm{~S}$ rRNA gene reads). Sulfurimonas $\mathrm{GD} 1^{\mathrm{T}} / \mathrm{GD} 17$-specific CARDFISH analyses using gene probe Sul90 confirmed these high 16S rRNA gene abundances for redox zone samples collected from the Landsort Deep under optimal $\mathrm{H}_{2} \mathrm{~S}$ concentrations of $6.8 \mu \mathrm{mol} \mathrm{L}^{-1}$ (Figs. 2a, 3b; Supplementary Table S2), in which Sulfurimonas $\mathrm{GD}^{\mathrm{T}}$ / GD17 subgroup cell abundances within the P2 cluster were 94 and $97 \%$. By contrast, in the control group (low side scatter cells), Sul90-positive cells contributed only between 0.7 and $2.1 \%$ of the cells outside the P2 cluster (Supplementary Table S2), and thus were at the detection limit of this approach. At the deepest depths and in a highly sulfidic zone, the fraction of Sul90-positive cells in the P2 cluster decreased down to $17 \%$ (Fig. 2). 


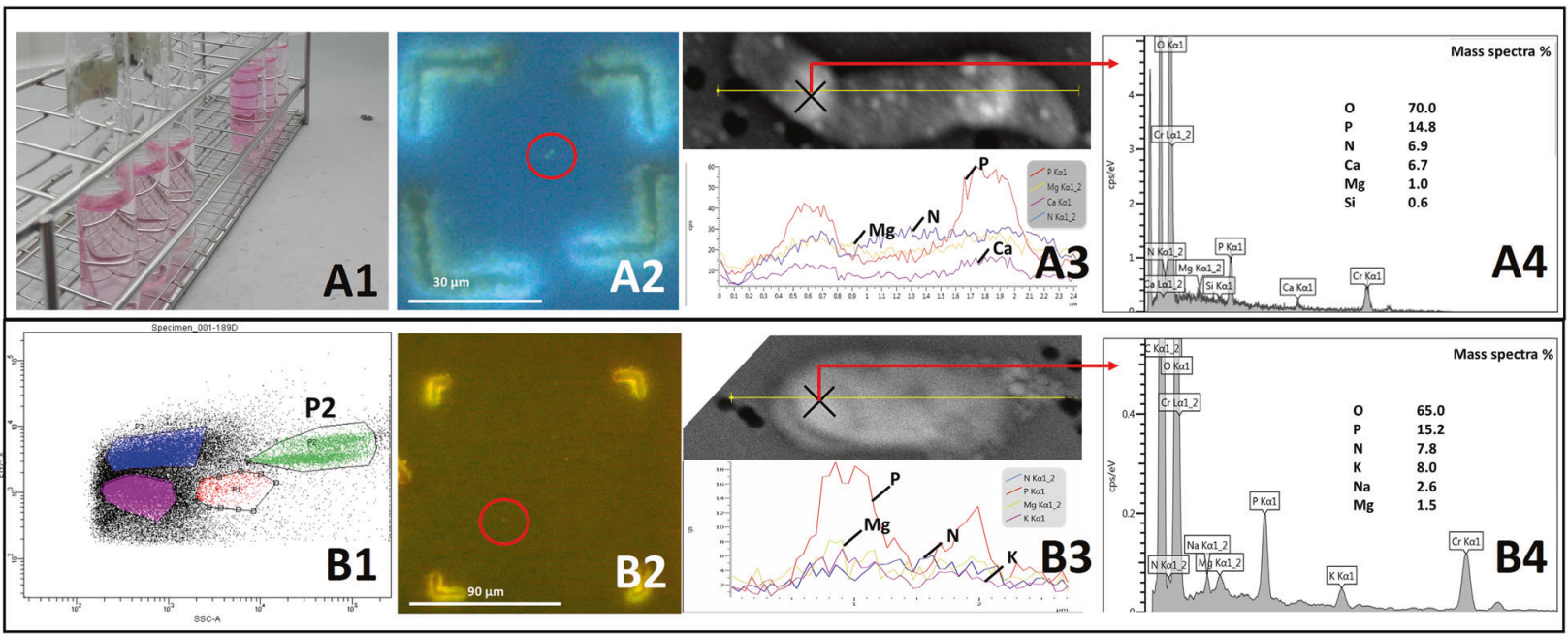

Fig. 4 Approach to detect polyphosphate inclusions in Sulfurimonas GD ${ }^{\mathrm{T}} / \mathrm{GD} 17$ cells in culture and environmental samples. a1 The cells were harvested directly from $S$. gotlandica $\mathrm{GD} 1^{\mathrm{T}}$ cultures. b1 Sulfurimonas GD17 cells were collected by FACS from environmental samples. GD17 forms the distinct pattern P2 when analyzed by flow cytometry. a2 Identification and marking of single $S$. gotlandica $\mathrm{GD} 1^{\mathrm{T}}$ cells with yellow inclusions after DAPI staining. b2 SYBRGreenstained Sulfurimonas GD17 cells isolated by FACS were identified by marking with the Laser Microdissection Microscope (LMD). a3, b3

\section{Polyphosphate accumulation in Sulfurimonas cells in situ and in vitro}

\section{In situ polyphosphate accumulation in Sulfurimonas subgroup GD17 cells}

Following the sorting and identification of Sulfurimonas GD17/GD1 ${ }^{\mathrm{T}}$ dominated P2 clusters from the Gulf of Finland and the Landsort Deep, as described above, these samples were subjected to SEM-EDX particle analyses. The $5.9 \%( \pm 5.1 \%)$ of the automatically detected particles could manually be identified as bacterial cells (1153 cells overall), with total numbers in the range from 85 to 295 cells per sample (Fig. 2). Of the cells originating from the P2 cluster of station F3, 91.8\% (79 m) contained phosphorus. The P2 cluster taken $2 \mathrm{~m}$ above at $77 \mathrm{~m}$ depth did not contain phosphorus-positive cells anymore. All the other P2 clusters analyzed contained between 0.0 and $2.1 \%$ phosphorusenriched cells. The evidence of inorganic polyphosphate in cells of the P2 cluster using the line scan mode was obtained from station F3 at $79 \mathrm{~m}$ (Fig. 4b3). At this depth, the abundance of the $\mathrm{P} 2$ cluster was high, $>4.36 \times 10^{5}$ cells $\mathrm{mL}$ ${ }^{-1}$ (Fig. 2). In comparison to cultured $\mathrm{GD}^{\mathrm{T}}$ cells, polyphosphate of the environmental P2 cluster cells contained potassium instead of calcium (Fig. 4b4). In contrast, sulfur or nitrate enrichments were undetectable in any cell or bulk of cells investigated by EDX. Thus, Sulfurimonas subgroup GD17 enriched polyphosphate in areas of pelagic redox zones where sulfide/nitrate overlaps may occur. To confirm
The marked cells were line-scanned for the distribution of phosphorus, nitrogen, magnesium, and potassium, or calcium over the whole cell body. The crosses mark the spots analyzed in greater detail by EDX point analysis $(\mathbf{a 4}, \mathbf{b 4})$. Specific cross-marked areas were analyzed for their elemental composition. Relative abundances (\%) correspond to those elements in the marked spot included in the analysis. Two elements visible in the EDX spectra were excluded from calculation: carbon, which was the filter material, and chromium, used as the sputter element for conductivity

these conditions as relevant ecological factors, the impact of different substrates and substrate concentrations on polyphosphate formation in Sulfurimonas gotlandica $\mathrm{GD} 1^{\mathrm{T}}$ cells were investigated.

\section{In vitro polyphosphate accumulation in Sulfurimonas gotlandica $\mathrm{GD}^{\top}{ }^{\top}$ cells at different catabolite concentrations}

Independent of the electron donor type, yellow inclusions were only seen in larger amounts in DAPI-stained, stationary-phase $S$. gotlandica strain $\mathrm{GD} 1^{\mathrm{T}}$ cells cultivated in the presence of high concentrations $\left(5\right.$ or $10 \mathrm{mmol} \mathrm{L}^{-1}$ ) of the electron donor/acceptor (thiosulfate: in $94.4 \%$ $( \pm 3.7 \%)$ of total cells; sulfur: in $7.5 \%( \pm 5.2 \%)$ of total cells). Lower concentrations $\left(100 \mu \mathrm{mol} \mathrm{L}^{-1}\right)$ resulted in cell growth but fewer or no visible inclusions (thiosulfate: in $0.1 \%( \pm 0.3 \%)$ of total cells; sulfur: in $1.4 \%( \pm 1.7 \%)$ of total cells). Point measurements as well as line scans during SEM-EDX-based elemental composition analyses of cells containing these inclusions (Fig. 4a3, 4) revealed the presence of phosphorus in combination with magnesium and calcium. In polyphosphate-free cells, phosphorus was below the detection limit of this approach.

\section{Polyphosphate enrichment at different substrates and growth phases}

Cellular polyphosphate and protein production depended on the applied electron donor and the growth phase (Table 1). 


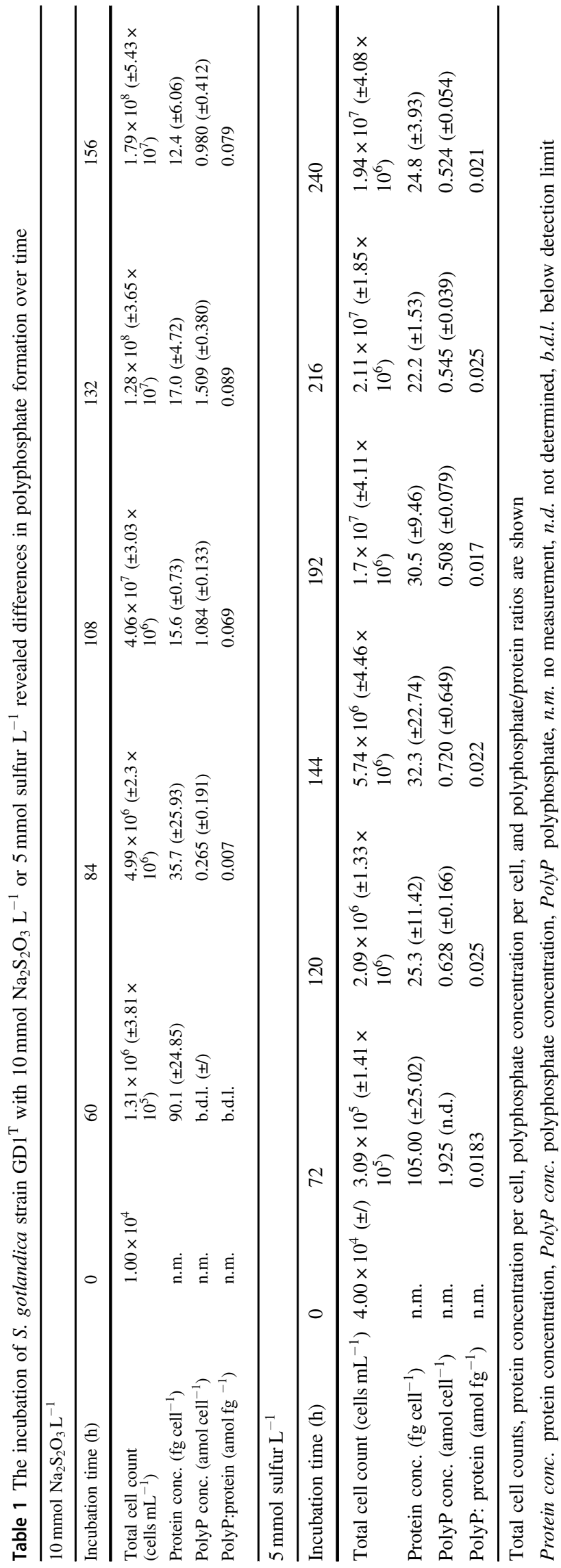

For cells grown on thiosulfate the exponential phase was between 60 and $132 \mathrm{~h}$ of incubation $(k=0.066)$, while for sulfur cultures the exponential growth phase was between 72 and $144 \mathrm{~h}(k=0.041)$. In elemental sulfur incubations, the polyphosphate/protein ratio was nearly constant over time; between 0.017 and $0.025 \mathrm{amol}\left(10^{-18}\right) \mathrm{fg}^{-1}$, with a mean polyphosphate enrichment of $0.81( \pm 0.55)$ amol per cell. In thiosulfate incubations, the polyphosphate/protein ratio followed the growth curve and increased over time from 0.007 up to $0.089 \mathrm{amol} \mathrm{fg}^{-1}$ at the end of the exponential phase (Table 1). Based on a polyphosphate content of $1.51( \pm 0.38)$ amol per cell, the maximal polyphosphate enrichment occurred after $132 \mathrm{~h}$ of incubation in thiosulfate medium.

\section{Cellular integrity at different cellular polyphosphate concentrations}

The theoretical benefit of polyphosphate enrichment could be the maintenance of cellular integrity at nutrient-limited conditions in a pelagic redox zone for a certain time. To gain first insights into this, S. gotlandica $\mathrm{GD}^{\mathrm{T}}$ cultures containing high and low cellular polyphosphate concentrations were incubated in electron donor-free media for 90 days and their survival rate determined.

Cells containing high or low amounts of polyphosphate were used (after two washing steps in nutrient-free ABW) at starting densities of $2.0 \times 10^{9}$ cells. The polyphosphate/ protein ratio of the polyphosphate-rich approach was 0.049 amol fg$^{-1}$, with $98 \%$ of all DAPI-stained cells containing visible polyphosphate inclusions, and below the detection limit of $0.025 \mathrm{amol} \mathrm{fg}^{-1}$ for the polyphosphate-low approach. After 90 days, no polyphosphate was detectable anymore in both approaches. While cell abundances of both groups decreased (initially high-polyphosphate group by $84.0 \%( \pm 9.0 \%)$ and low-polyphosphate group by $99.0 \%$ $( \pm 0.3 \%)$ ), a significantly larger number of initially highpolyphosphate-containing cells (Mann-Whitney test, $p<$ 0.05 ; with more than one magnitude difference) maintained visible cellular integrity.

Taken together, our data point to the role of polyphosphate as a cellular energy source under low-nutrient conditions.

\section{Ecological features of Sulfurimonas gotlandica GD1 ${ }^{\top}$ potentially associated with polyphosphate generation}

To reach favorable niches in an unstable environment, Sulfurimonas subgroup GD17/GD1 ${ }^{\mathrm{T}}$ requires the ability: (1) to identify zones of optimal nutrient conditions and (2) to reach these zones quickly before they disappear. In consequence, both the ability of $\mathrm{GD} 1^{\mathrm{T}}$ to identify optimal nutrient conditions within a thiosulfate-nitrate gradient and the maximal motility speed achieved were respectively investigated. 
Cellular identification of optimal substrate concentrations in a thiosulfate-nitrate gradient

At all electron donor/acceptor concentrations tested in the gradient experiments, $S$. gotlandica $\mathrm{GD}^{\mathrm{T}}$ formed distinct patterns in the glass tubes after 23 days of incubation. At higher nutrient concentrations, the fractions containing the highest cell abundances generally became proportionally larger, with the cells in those fractions moving towards the $\mathrm{KNO}_{3}$-containing top agar. Thus, in a gradient system, $\mathrm{GD} 1^{\mathrm{T}}$ actively moved and stayed in specific areas favorable for its growth (Supplementary Table S3).

\section{Motility speed of $\mathrm{GD} 1^{\top}$ cells}

After their incubation for 7 days (late exponential growth phase), motile cells had a mean speed of $15-40 \mu \mathrm{m} \mathrm{s}^{-1}$ (Supplementary Table S4; independent of the electron acceptor/donor concentration), but reached a maximum speed of $158 \mu \mathrm{m} \mathrm{s}^{-1}$ (data not shown). There was no significant trend indicating a relationship between electron acceptor/ donor concentrations and the speed of the motile cells.

\section{Discussion}

Our SEM-EDX analyses showed that Sulfurimonas cells became enriched in phosphorus in the form of polyphosphate, as they were detected together with an increase in magnesium and potassium (environmental samples) or calcium (cultures). Negatively charged polyphosphate is typically associated with positively charged ions, with valences of both +1 and +2 [44-46]. Similar EDX results have already been reported for polyphosphate inclusions [47, 48]. In addition, GD1 ${ }^{\mathrm{T}}$ DAPIstained cells contained bright yellow inclusions and thus differed in their appearance from otherwise blue DAPIstaining cells. This metachromatic shift was due to the interaction of the dye with a polyanionic substance, in this case polyphosphate $[49,50]$. While there are alternative, multiple, negatively charged substances possibly explaining this spectral change [48, 51, 52], the combination of phosphorous detected in EDX analyses and the observed metachromatic shift provided reliable evidence that the Sulfurimonas inclusions consisted of polyphosphate.

\section{Requirements for polyphosphate accumulation in $S$. gotlandica GD1 ${ }^{\top}$}

Polyphosphate inclusions in cells of $S$. gotlandica strain $\mathrm{GD} 1^{\mathrm{T}}$ were also detected in situ, in analyses of environmental samples, thus confirming that our results were not a culture-dependent artifact. However, among all the environmental samples analyzed, in only one such sample (which co-occurred with maximum abundances of the GD17/GD1 ${ }^{\mathrm{T}}$ cluster) was polyphosphate detected in $98.1 \%$ of all cells, whereas for all the other samples it was $\leq 2.1 \%$. The considerably higher cell abundance in this zone suggests that it provides favorable environmental conditions for $\mathrm{GD}^{\mathrm{T}}$ cells. This was confirmed in the cultivation experiments, in which high concentrations of electron donors resulted in more pronounced polyphosphate inclusions, and low concentrations exhibited either low amounts or no polyphosphate inclusions at all. These results suggested that significant polyphosphate accumulation, evidenced by distinguishable inclusions, occur only under favorable conditions. Yet, while distinguishable inclusions were consistently seen in batch cultures, they were a rare occurrence in environmental samples.

The presence of different available electron donors resulted in different polyphosphate contents in $\mathrm{GD} 1^{\mathrm{T}}$ cultures and also in variations of polyphosphate formation timing (Table 1). Polyphosphate accumulation in accordance with the growth phase and available energy source has been demonstrated in other microorganisms [53, 54]. In culture medium containing thiosulfate, polyphosphate was formed during the exponential growth phase. However, as soon as the cells entered stationary phase, the polyphosphate content remained constant or began to decrease. This is probably due to the complete consumption of electron donors during that growth phase [55].

In cultures supplemented with elemental sulfur, the nearly constant amount of polyphosphate may have reflected the fact that elemental sulfur hardly dissolves in pure water and even less in sea water [56]. Under the tested conditions, $<10 \mathrm{nmol}$ sulfur $\mathrm{L}^{-1}$ is dissolved in $\mathrm{ABW}$ medium [57]. Therefore, in addition to growth, polyphosphate production by $\mathrm{GD} 1^{\mathrm{T}}$ seems to be highly dependent on the bioavailability of sulfur, such that only bacterial cells in direct contact with sulfur are probably able to produce high-energy-containing polyphosphate.

Thiosulfate was better than elemental sulfur in promoting polyphosphate production by $\mathrm{GD}^{\mathrm{T}}$ cells. The probable difference can be explained by access to the electron donor, because the formation of high-energycontaining polyphosphate is only possible when an efficient supply is provided. Further investigations using other electron donors such as pyruvate and hydrogen sulfide will provide further insights into the relationship between polyphosphate formation and the availability of suitable electron donors.

\section{Polyphosphate accumulation pathways in $S$. gotlandica GD1 ${ }^{\top}$}

S. gotlandica $\mathrm{GD} 1^{\mathrm{T}}$ contains a number of genes associated with both polyphosphate formation and degradation [12] 


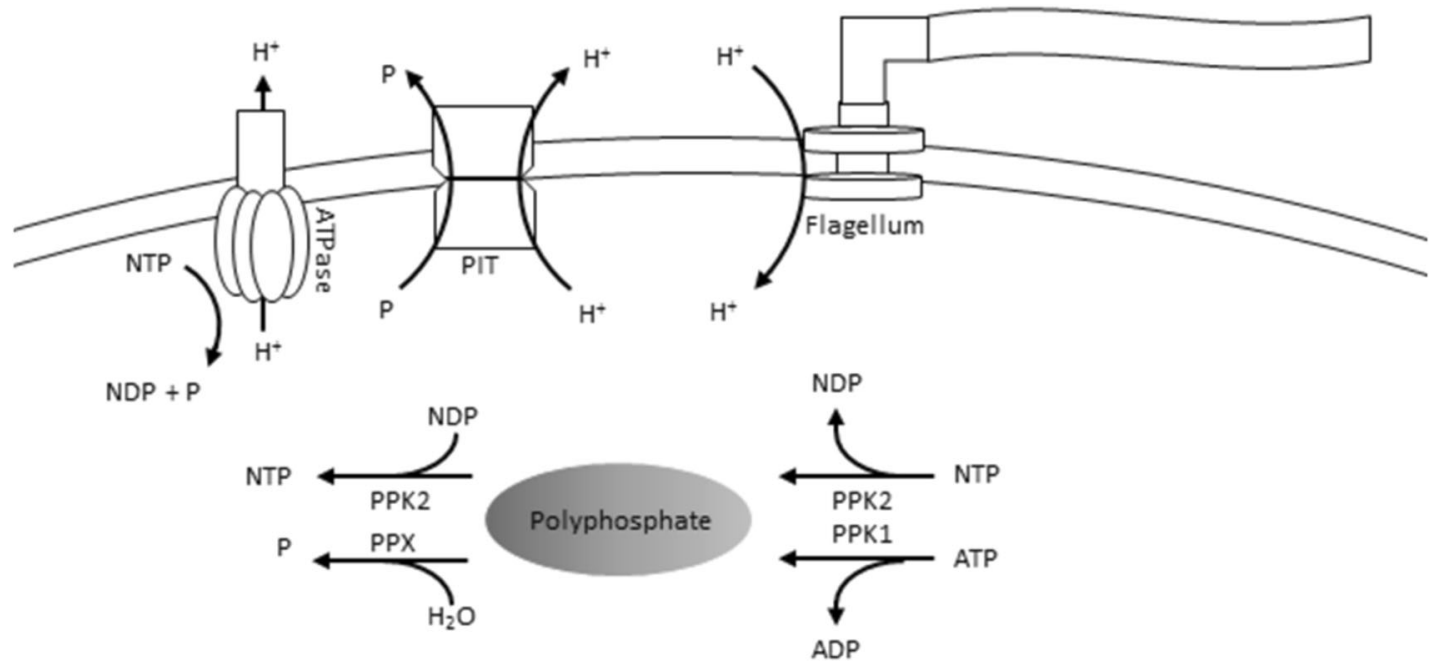

Fig. 5 Hypothesized use of polyphosphate for energy storage and motility of $S$. gotlandica GD $1^{\mathrm{T}}$ cells. Polyphosphate kinase 1 family ( $p p k 1)$ enzymes catalyze the formation of polyphosphate from ATP. Polyphosphate kinase 2 family ( $p p k 2$ ) enzymes produce nucleoside triphosphate (NTP) from phosphate and nucleoside diphosphate

and therefore also has the potential for polyphosphate anabolism and catabolism (Fig. 5). Three of these genes encode polyphosphate kinase enzymes belonging to the type 2 family (ppk2 [12]) which, unlike the type 1 family (ppk1), preferentially degrade polyphosphate to achieve purine phosphorylation [58-60]. One of the ppk2 genes in the $\mathrm{GD} 1^{\mathrm{T}}$ genome (NCBI accession: WP_008335082.1) was classified into the PA0141 family (using InterPro66.0), for which the activity has been tested in Pseudomonas aeruginosa. This enzyme catalyzes the synthesis of ATP in a reaction in which polyphosphate dephosphorylation is coupled to adenosine diphosphate (ADP) phosphorylation [59]. Another enzyme is an RNA degradosome polyphosphate kinase which is similar to the ppk1 from Escherichia coli $[\mathrm{P} 0 \mathrm{~A} 7 \mathrm{~B} 1]$. The $S$. gotlandica strain $\mathrm{GD} 1^{\mathrm{T}}$ genome also contains an exopolyphosphatase ( $p p x)$ that catalyzes the hydrolysis of terminal phosphate residues from polyphosphate chains, as well as enzymes comprising a low-affinity Pi transport system (Pit) thought to play a role in the production of energy from polyphosphate through the generation of a proton-motive force [61, 62].

Members of the Epsilonproteobacteria isolated from marine sediments were recently shown to utilize all of the above-mentioned genes, particularly $p p k 2$, under both anoxic and sulfidic conditions [63]. The authors proposed that these bacteria are able to concurrently engage in sulfur oxidation and polyphosphate degradation [63]. Our results show that the $S$. gotlandica strain $\mathrm{GD}^{\mathrm{T}}$ genome confers other possibilities for polyphosphate utilization which, analogously, may be widely distributed.
(NDP). Exopolyphosphatase ( $p p x)$ hydrolyzes the terminal phosphate from polyphosphate; the low-affinity Pi transport system (PIT) generates a proton-motive force via the symport of polyphosphate and protons

\section{Possible implications of polyphosphate accumulation in Sulfurimonas GD17/GD1 ${ }^{\top}$ cells for their ecology}

We hypothesized that $S$. gotlandica $\mathrm{GD}^{\mathrm{T}}$ cells accumulate polyphosphate in overlapping zones of pelagic redox zones where suitable electron acceptors and electron donors colocalize, using this polyphosphate as an energy source to sustain cellular integrity. Currently, the experimental results support important parts of our hypothesis. Specifically, the 90-day incubation experiment demonstrated that polyphosphate inclusions significantly assisted in maintaining the cellular integrity of $S$. gotlandica $\mathrm{GD} 1^{\mathrm{T}}$ cells under nutrientlimiting conditions for a 3-month time period.

However, more specifically in the context of maintenance energy, it could additionally be hypothesized that the sustainment of cellular integrity also sustains motility to reach new favorable zones under unfavorable conditions. Under nutrient starvation, maintenance energy defined as "...the energy consumed for functions other than the production of new cell material..." [64], including osmoregulation, synthesis of macromolecules, membrane energization and motility, has to be provided by endogenous substrates as, e.g., polyphosphate. It has been shown that prokaryotic cells can maintain motility under nutrient starvation. For instance, Vibrio anguillarium can stay motile for up to 8 days under these conditions [65] and Methanocaldococcus jannaschii only produces flagella relatedpolypeptides during energy limitation periods [66]. The reason is probably that motility, especially in combination 
with chemotaxis, can improve the supply of catabolites and by this increase cellular fitness [67]. Thus, the maintenance of motility by polyphosphate may also be an important feature for the survival of $S$. gotlandica GD17/GD1 ${ }^{\mathrm{T}}$ in pelagic redox zones. In principal, the theoretical benefit of this form of energy storage, if solely used for movement, can be considered. For this we assumed that: (i) the storage of internal polyphosphate based on thiosulfate-grown cultures is between 0.27 and $1.51 \mathrm{amol} \mathrm{cell}^{-1}$ (Table 1), (ii) polyphosphate chain lengths are comparable in situ to those used in standard experiments (45 residues), (iii) the energy content of a phosphoric acid bond is $30.5 \mathrm{~kJ} \mathrm{~mol}^{-1}$ and (iv) bacterial swimming efficiency is in the range of $5.1 \times 10^{9} \mathrm{~m}$ $\mathbf{J}^{-1}$ to $7.3 \times 10^{9} \mathrm{~m} \mathrm{~J}^{-1}[68]$. Under these conditions, the resulting maximum migration distance would be $0.2-1.5 \mathrm{~cm}$ (Supplementary material, text 1), which is sufficient to overcome small-scale turbulences. This hypothesis would be supported by the fact that $\mathrm{GD} 1^{\mathrm{T}}$ cells can, independent of their supply of electron donors and acceptors and the range of substrate concentrations tested, swim fast, with nearly $160 \mu \mathrm{m} \mathrm{s}^{-1}$, thus enabling the cells to reach favorable zones quickly (Supplementary Table S4). Finally, it was shown that $\mathrm{GD} 1^{\mathrm{T}}$ cells can indeed actively localize these zones (Supplementary Table S3), probably based on chemotaxis towards nitrate [12].

The redox zone of the Baltic Sea is characterized by a changing redox potential induced by local mixing events [15] which introduce nitrate-containing water masses into sulfidic zones and vice versa. Given this turbulent environment, the ability to store polyphosphate to maintain cellular integrity, and potentially linked to motility, and thus improve localization would provide a valuable survival advantage and can therefore be considered a valuable niche adaption for motile bacteria in pelagic Baltic Sea redox zones. In fact, a comparative analysis of the functional capacity of Landsort Deep metagenomes showed that the proportion of genes responsible for chemotaxis and movement was much higher in cells from hypoxic water masses than in those from other ecosystems also characterized by redox gradients [69]. Even in ecosystems where there is no redox gradient, the micro-scale patchiness of available nutrients results in differences in bacterioplankton assemblages at a millimeter scale [70]. The adoption of a chemotactic response to micro-scale perturbations was previously shown to provide a significant advantage for heterotrophs, by enabling a much higher exposure to nutrients [71]. Our results could present a similar case for the chemolithoautotrophic bacteria that occupy redox gradients within eutrophic ecosystems perturbed by temporally and spatially limited mixing events; future analyses should especially aim to directly confirm this hypothesis with regard to maintenance of motility.

\section{Conclusion}

Our study demonstrated the storage of inorganic polyphosphate by cells of Sulfurimonas subgroup GD17/GD1 ${ }^{\mathrm{T}}$ cells, both in vitro and in situ. However, in environmental samples, polyphosphate storage was detected only in cells inhabiting a zone close to the chemocline and present in considerably higher abundances than in other parts of the redox zone. These results suggest that: (i) polyphosphate accumulates only under favorable conditions, defined as the exposure to sufficient amounts of electron acceptors/donors and (ii) that polyphosphate is used to maintain cellular integrity. This redox-independent energy supply could be a prerequisite for the maintenance of the $r$-strategy lifestyle of Sulfurimonas subgroup GD17/GD1 ${ }^{\mathrm{T}}$ and may generally represent a newly identified survival strategy for chemolithoautotrophic prokaryotes occupying eutrophic redox zones.

Acknowledgements We are grateful to the captains and crews of the R/ V Salme and R/V Poseidon. The excellent technical assistance of Ronny Baaske, Heike Brockmöller, Sascha Plewe, and Fabiola Henning is greatly appreciated. Special thanks goes to Heribert Cypionka for his essential advice concerning the freeware program "Trace"; and HC as well as Heide Schulz-Vogt for helpful discussions. We thank the Deutsche Forschungsgemeinschaft (DFG) for grants LA 1466/4-1, 4-2, the Baltisch-Deutsches Hochschulkontor, and the Leibniz Institute for Baltic Sea Research Warnemünde (IOW) for funding.

\section{Compliance with ethical standards}

Conflict of interest The authors declare that they have no conflict of interest.

\section{References}

1. Carstensen J, Andersen JH, Gustafsson BG, Conley DJ. Deoxygenation of the Baltic Sea during the last century. Proc Natl Acad Sci USA. 2014;111:5628-33.

2. Conley DJ, Björck S, Bonsdorff E, Carstensen J, Destouni G, Gustafsson BG, et al. Hypoxia-related processes in the Baltic Sea. Environ Sci Technol. 2009;43:3412-20.

3. Jørgensen BB, Fossing H, Wirsen CO, Jannasch HW. Sulfide oxidation in the anoxic Black Sea chemocline. Deep Sea Res Part 1 Oceanogr Res Pap. 1991;38:1083-103.

4. Taylor GT, Iabichella M, Ho TY, Scranton MI, Thunell RC, Muller-Karger F, et al. Chemoautotrophy in the redox transition zone of the Cariaco Basin: a significant mid-water source of organic carbon production. Limnol Oceanogr. 2001;46: 148-63.

5. Brettar I, Rheinheimer G. Denitrification in the central Baltic: evidence for $\mathrm{H}_{2} \mathrm{~S}$-oxidation as motor of denitrification at the oxicanoxic interface. Mar Ecol Prog Ser. 1991;77:157-69.

6. Brüchert V, Jørgensen BB, Neumann K, Riechmann D, Schlösser M, Schulz H. Regulation of bacterial sulfate reduction and hydrogen sulfide fluxes in the central Namibian coastal upwelling zone. Geochim Chosmochim Acta. 2003;67:4505-18.

7. Canfield DE, Stewart FJ, Thamdrup B, De Brabandere L, Dalsgaard T, DeLong EF, et al. A cryptic sulfur cycle in oxygen- 
minimum-zone waters off the Chilean Coast. Science. 2010;330:1375-8.

8. Lam P, Kuypers MM. Microbial nitrogen cycling processes in oxygen minimum zones. Ann Rev Mar Sci. 2011;3:317-45.

9. Grote J, Labrenz M, Pfeiffer B, Jost G, Jürgens K. Quantitative distributions of Epsilonproteobacteria and a Sulfurimonas subgroup in pelagic redoxclines of the central Baltic Sea. Appl Environ Microbiol. 2007;73:7155-61.

10. Labrenz M, Brettar I, Christen R, Flavier S, Botel J, Höfle MG. Development and application of a real-time PCR approach for quantification of uncultured bacteria in the central Baltic Sea. Appl Environ Microbiol. 2004;70:4971-9.

11. Brettar I, Labrenz M, Flavier S, Botel J, Kuosa H, Christen R, et al. Identification of a Thiomicrospira denitrificans-like epsilonproteobacterium as a catalyst for autotrophic denitrification in the central Baltic Sea. Appl Environ Microbiol. 2006;72:1364-72.

12. Grote J, Schott T, Bruckner CG, Glöckner FO, Jost G, Teeling H, et al. Genome and physiology of a model Epsilonproteobacterium responsible for sulfide detoxification in marine oxygen depletion zones. Proc Natl Acad Sci USA. 2012;109:506-10.

13. Rogge A, Vogts A, Voss M, Jürgens K, Günter J, Labrenz M. NanoSIMS analyses reveal different lifestyles of chemolithoautotrophic SUP05 and Sulfurimonas GD17 cells in a pelagic Baltic Sea redox zone. Env Microbiol. 2017;19:2495-506.

14. Labrenz M, Grote J, Mammitzsch K, Boschker HTS, Laue M, Jost G, et al. Sulfurimonas gotlandica sp. nov., a chemoautotrophic and psychrotolerant epsilonproteobacterium isolated from a pelagic redoxcline, and an emended description of the genus Sulfurimonas. Int J Syst Evol Micr. 2013;63:4141-8.

15. Axell LB. On the variability of Baltic Sea deepwater mixing. J Geophys Res Oceans. 1998;103:21667-82.

16. Otte S, Kuenen JG, Nielsen LP, Paerl HW, Zopfi J, Schulz HN, et al. Nitrogen, carbon, and sulfur metabolism in natural Thioploca samples. Appl Environ Microbiol. 1999;65:3148-57.

17. Pasteris JD, Freeman JJ, Goffredi SK, Buck KR. Raman spectroscopic and laser scanning confocal microscopic analysis of sulfur in living sulfur-precipitating marine bacteria. Chem Geol. 2001;180:3-18.

18. Preisler A, De Beer D, Lichtschlag A, Lavik G, Boetius A, Jørgensen BB. Biological and chemical sulfide oxidation in a Beggiatoa inhabited marine sediment. ISME J. 2007;1:341-53.

19. Schulz HN. The genus Thiomargarita. In: Dworkin M, Falkow S, Rosenberg E, Schleifer K-H, Stackebrandt E, editors. The prokaryotes. New York: Springer; 2006. p. S. 1156-63.

20. Brock J, Schulz-Vogt HN. Sulfide induces phosphate release from polyphosphate in cultures of a marine Beggiatoa strain. ISME J. 2011;5:497-506.

21. Harold FM. Depletion and replenishment of the inorganic polyphosphate pool in Neurospora crassa. J Bacteriol. 1962;83:1047-57.

22. Kornberg A. Inorganic polyphosphate: toward making a forgotten polymer unforgettable. J Bacteriol. 1995;177:491-6.

23. Baker AL, Schmidt RR. Induced utilization of polyphosphate during nuclear division in synchronously growing. Chlorella BBA Gen Subj. 1964;93:180-2.

24. Hsieh PC, Shenoy BC, Haase FC, Jentoft JE, Phillips NF. Involvement of tryptophan(s) at the active site of polyphosphate/ ATP glucokinase from Mycobacterium tuberculosis. Biochemistry. 1993;32:6243-9.

25. Skorko R. Polyphosphate as a source of phosphoryl group in protein modification in the archaebacterium Sulfolobus acidocaldarius. Biochimie. 1989;71:1089-93.

26. Ault-Riché D, Fraley CD, Tzeng C-M, Kornberg A. Novel assay reveals multiple pathways regulating stress-induced accumulations of inorganic polyphosphate in Escherichia coli. J Bacteriol. 1998;180:1841-7.
27. Rao NN, Kornberg A. Inorganic polyphosphate supports resistance and survival of stationary-phase Escherichia coli. J Bacteriol. 1996;178:1394-400.

28. Sureka K, Dey S, Datta P, Singh AK, Dasgupta A, Rodrigue S, et al. Polyphosphate kinase is involved in stress-induced $m p r A B$ sigE-rel signalling in mycobacteria. Mol Microbiol. 2007;65: 261-76.

29. Kim HY, Schlictman D, Shankar S, Xie Z, Chakrabarty AM, Kornberg A. Alginate, inorganic polyphosphate, GTP and ppGpp synthesis co-regulated in Pseudomonas aeruginosa: implications for stationary phase survival and synthesis of RNA/DNA precursors. Mol Microbiol. 1998;27:717-25.

30. Pick U, Chitlaru E, Weiss M. Polyphosphate-hydrolysis-a protective mechanism against alkaline stress? FEBS Lett. 1990;274:15-8.

31. Blum E, Py B, Carpousis AJ, Higgins CF. Polyphosphate kinase is a component of the Escherichia coli RNA degradosome. Mol Microbiol. 1997;26:387-98.

32. Bonting CF, Kortstee GJ, Zehnder AJ. Properties of polyphosphate: AMP phosphotransferase of Acinetobacter strain 210A. J Bacteriol. 1991;173:6484-8.

33. Seufferheld MJ, Alvarez HM, Farias ME. Role of polyphosphates in microbial adaptation to extreme environments. Appl Environ Microbiol. 2008;74:5867-74.

34. Varela C, Mauriaca C, Paradela A, Albar JP, Jerez CA, Chávez FP. et al. New structural and functional defects in polyphosphate deficient bacteria: a cellular and proteomic study. BMC Microbiol. 2010;10:7

35. Rivas-Lamelo S, Benzerara K, Lefèvre CT, Monteil CL, Jézéquel $\mathrm{D}$, Menguy N. et al. Magnetotactic bacteria as a new model for $\mathrm{P}$ sequestration in the ferruginous Lake Pavin. Geochem Persp Let. 2017;5:35-41.

36. Jost G, Zubkov MV, Yakushev E, Labrenz M, Jürgens K. High abundance and dark $\mathrm{CO}_{2}$ fixation of chemolithoautotrophic prokaryotes in anoxic waters of the Baltic Sea. Limnol Oceanogr. 2008;53:14-22.

37. Laas P, Šatova E, Lips I, Lips U, Simm J, Kisand V, et al. Nearbottom hypoxia impacts dynamics of bacterioplankton assemblage throughout water column of the Gulf of Finland (Baltic Sea). PloS ONE. 2016;11:e0156147.

38. Bruns A, Cypionka H, Overmann J. Cyclic AMP and acyl homoserine lactones increase the cultivation efficiency of heterotrophic bacteria from the central Baltic Sea. Appl Environ Microbiol. 2002;68:3978-87.

39. Martin P, Van Mooy BA. Fluorometric quantification of polyphosphate in environmental plankton samples: extraction protocols, matrix effects, and nucleic acid interference. Appl Environ Microbiol. 2013;79:273-81.

40. Kulakova AN, Hobbs D, Smithen M, Pavlov E, Gilbert JA, Quinn JP, et al. Direct quantification of inorganic polyphosphate in microbial cells using 4'-6-diamidino-2-phenylindole (DAPI). Environ Sci Technol. 2011;45:7799-803.

41. Fischer JP, Cypionka H. Analysis of aerotactic band formation by Desulfovibrio desulfuricans in a stopped-flow diffusion chamber. FEMS Microbiol Ecol. 2006;55:186-94.

42. Adler J, Dahl MM. A method for measuring the motility of bacteria and for comparing random and non-random motility. J Gen Microbiol. 1967;46:161-73.

43. Grote J, Jost G, Labrenz M, Herndl GJ, Jürgens K. Epsilonproteobacteria represent the major portion of chemoautotrophic bacteria in sulfidic waters of pelagic redoxclines of the Baltic and Black Seas. Appl Environ Microbiol. 2008;74: 7546-51.

44. Friedberg I, Avigad G. Structures containing polyphosphate in Micrococcus lysodeikticus. J Bacteriol. 1968;96:544-53. 
45. Morrissey JH, Choi SH, Smith SA. Polyphosphate: an ancient molecule that links platelets, coagulation, and inflammation. Blood. 2012;119:5972-9.

46. Peverly JH, Adamec J, Parthasarathy MV. Association of potassium and some other monovalent cations with occurrence of polyphosphate bodies in Chlorella pyrenoidosa. Plant Physiol. 1978;62:120-6.

47. Gomes F, Ramos I, Wendt C, Girard-Dias W, De Souza W, Machado EA, et al. New insights into the in situ microscopic visualization and quantification of inorganic polyphosphate stores by 4', 6-diamidino-2-phenylindole (DAPI)-staining. Eur J Histochem. 2013;57:227-5.

48. Liu WT, Nielsen AT, Wu JH, Tsai CS, Matsuo Y, Molin S. In situ identification of polyphosphate-and polyhydroxyalkanoate-accumulating traits for microbial populations in a biological phosphorus removal process. Environ Microbiol. 2001;3:110-22.

49. Kulaev IS, Vagabov VM, Kulakovskaya TV. Localization of polyphosphates in cells of prokaryotes and eukaryotes. In: Kulaev IS, Vagabov VM, Kulakovskaya TV, editors. The biochemistry of inorganic polyphosphates. 2nd ed. Chichester: John Wiley \& Sons; 2004. p. 53-4.

50. Tijssen JPF, Beekes HW, Van Steveninck J. Localization of polyphosphates in Saccharomyces fragilis, as revealed by 4', 6diamidino-2-phenylindole fluorescence. BBA-Mol Cell Res. 1982;721:394-8.

51. Kolozsvari B, Parisi F, Saiardi A. Inositol phosphates induce DAPI fluorescence shift. Biochem J. 2014;460:377-85.

52. Streichan M, Golecki JR, Schön G. Polyphosphate-accumulating bacteria from sewage plants with different processes for biological phosphorus removal. FEMS Microbiol Ecol. 1990;6:113-24.

53. Chávez FP, Lünsdorf $\mathrm{H}$, Jerez CA. Growth of polychlorinatedbiphenyl-degrading bacteria in the presence of biphenyl and chlorobiphenyls generates oxidative stress and massive accumulation of inorganic polyphosphate. Appl Environ Microbiol. 2004;70:3064-72.

54. Clark JE, Beegen H, Wood HG. Isolation of intact chains of polyphosphate from" Propionibacterium shermanii" grown on glucose or lactate. J Bacteriol. 1986;168:1212-9.

55. Mammitzsch K, Jost G, Jürgens K. Impact of dissolved inorganic carbon concentrations and $\mathrm{pH}$ on growth of the chemolithoautotrophic epsilonproteobacterium Sulfurimonas gotlandica $\mathrm{GD} 1^{\mathrm{T}}$. MicrobiologyOpen. 2014;3:80-88.

56. Tebbe FN, Wasserman E, Peet WG, Vatvars A, Hayman AC. Composition of elemental sulfur in solution: equilibrium of S6, S7 and S8 at ambient temperatures. J Am Chem Soc. 1982;104:4971-2.

57. Kamyshny JrA. Solubility of cyclooctasulfur in pure water and sea water at different temperatures. Geochim Cosmochim Acta. 2009;73:6022-8.
58. Ahn K, Kornberg A. Polyphosphate kinase from Escherichia coli. Purification and demonstration of a phosphoenzyme intermediate. J Biol Chem. 1990;265:11734-9.

59. Motomura K, Hirota R, Okada M, Ikeda T, Ishida T, Kuroda A. A new subfamily of polyphosphate kinase 2 (class III PPK2) catalyzes both nucleoside monophosphate phosphorylation and nucleoside diphosphate phosphorylation. Appl Environ Microbiol. 2014;80:2602-8.

60. Sureka K, Sanyal S, Basu J, Kundu M. Polyphosphate kinase 2: a modulator of nucleoside diphosphate kinase activity in mycobacteria. Mol Microbiol. 2009;74:1187-97.

61. Kawakoshi A, Nakazawa H, Fukada J, Sasagawa M, Katano Y, Nakamura S, et al. Deciphering the genome of polyphosphate accumulating actinobacterium Microlunatus phosphovorus. DNA Res. 2012;19:383-94.

62. Saunders AM, Mabbett AN, McEwan AG, Blackall LL. Proton motive force generation from stored polymers for the uptake of acetate under anaerobic conditions. FEMS Microbiol Lett. 2007;274:245-51.

63. Jones DS, Flood BE, Bailey JV. Metatranscriptomic insights into polyphosphate metabolism in marine sediments. ISME J. 2016;10:1015-9.

64. Pirt SJ. Maintenance energy of bacteria in growing cultures. Proc R Soc Lond B Biol Sci. 1965;163:224-31.

65. Larsen MH, Blackburn N, Larsen JL, Olsen JE. Influences of temperature, salinity and starvation on the motility and chemotactic response of Vibrio anguillarum. Microbiology. 2004;150:1283-90.

66. Mukhopadhyay B, Johnson EF, Wolfe RS. A novel $\mathrm{p}_{\mathrm{H} 2}$ control on the expression of flagella in the hyperthermophilic strictly hydrogenotrophic methanarchaeaon Methanococcus jannaschii. Proc Natl Acad Sci USA. 2000;97:11522-7.

67. Stocker R, Seymour JR, Samadani A, Hunt DE, Polz MF. Rapid chemotactic response enables marine bacteria to exploit ephemeral microscale nutrient patches. Proc Natl Acad Sci USA. 2008;105:4209-14.

68. Li G, Tang JX. Low flagellar motor torque and high swimming efficiency of Caulobacter crescentus swarmer cells. Biophys J. 2006;91:2726-34.

69. Thureborn P, Lundin D, Plathan J, Poole AM, Sjöberg B-M, Sjöling S. A metagenomics transect into the deepest point of the Baltic Sea reveals clear stratification of microbial functional capacities. PLOS ONE. 2013;8:e74983.

70. Long RA, Azam F. Antagonistic interactions among marine pelagic bacteria. Appl Environ Microbiol. 2001;67:4975-83.

71. Stocker R. Marine microbes see a sea of gradients. Science. 2012;338:628-33. 